\title{
CHLSOC: the Chilean Soil Organic Carbon database, a multi-institutional collaborative effort
}

\begin{abstract}
Marco Pfeiffer ${ }^{1}$, José Padarian ${ }^{2}$, Rodrigo Osorio ${ }^{3}$, Nelson Bustamante ${ }^{3}$, Guillermo Federico Olmedo $^{4,5}$, Mario Guevara $^{6}$, Felipe Aburto ${ }^{7}$, Francisco Albornoz ${ }^{8}$, Monica Antilén ${ }^{9,10}$, Elías Araya ${ }^{3}$, Eduardo Arellano ${ }^{11}$, Maialen Barret ${ }^{12}$, Juan Barrera ${ }^{13}$, Pascal Boeckx ${ }^{14}$, Margarita Briceño ${ }^{15}$, Sally Bunning ${ }^{16}$, Lea Cabrol ${ }^{17,18}$, Manuel Casanova ${ }^{1}$, Pablo Cornejo ${ }^{19}$, Fabio Corradini $^{20}$, Gustavo Curaqueo $^{21}$, Sebastian Doetterl ${ }^{22}$, Paola Duran ${ }^{19}$, Mauricio Escudey ${ }^{23,10}$, Angelina Espinoza ${ }^{24}$, Samuel Francke ${ }^{25}$, Juan Pablo Fuentes ${ }^{26}$, Marcel Fuentes ${ }^{27}$, Gonzalo Gajardo ${ }^{28}$, Rafael García ${ }^{29}$, Audrey Gallaud ${ }^{28}$, Mauricio Galleguillos ${ }^{30}$, Andrés Gomez ${ }^{3}$, Marcela Hidalgo ${ }^{13}$, Jorge Ivelic-Sáez ${ }^{31}$, Lwando Mashalaba $^{1}$, Francisco Matus ${ }^{19}$, Francisco Meza ${ }^{27}$, Maria de la Luz Mora ${ }^{19}$, Jorge Mora ${ }^{32}$, Cristina Muñoz $^{13}$, Pablo Norambuena ${ }^{33}$, Carolina Olivera ${ }^{34}$, Carlos Ovalle ${ }^{35}$, Marcelo Panichini ${ }^{36}$, Aníbal Pauchard $^{29}$, Jorge F. Pérez-Quezada ${ }^{30,41}$, Sergio Radic ${ }^{37}$, José Ramirez ${ }^{38}$, Nicolás Riveras ${ }^{1}$, Germán Ruiz $^{3}$, Osvaldo Salazar ${ }^{1}$, Iván Salgado ${ }^{3}$, Oscar Seguel ${ }^{1}$, Maria Sepúlveda ${ }^{13}$, Carlos Sierra ${ }^{27}$, Yasna Tapia ${ }^{1}$, Francisco Tapia ${ }^{27}$, Balfredo Toledo ${ }^{28}$, José Miguel Torrico ${ }^{39}$, Susana Valle ${ }^{40}$, Ronald Vargas $^{4}$, Michael Wolff ${ }^{36}$, and Erick Zagal ${ }^{13}$
\end{abstract}

${ }^{1}$ Departamento de Ingeniería y Suelos, Facultad de Ciencias Agronómicas, Universidad de Chile, Santa Rosa 11315, La Pintana, Chile

${ }^{2}$ Institute of Agriculture, The University of Sydney, New South Wales, Sydney, Australia

${ }^{3}$ Servicio Agrícola y Ganadero (SAG), Ministerio de Agricultura, Av. Presidente Bulnes 140, Santiago, Chile

${ }^{4}$ Food and Agriculture Organization of the United Nations (FAO), Viale delle Terme di Caracalla, Rome, Italy

${ }^{5}$ Instituto Nacional de Tecnología Agropecuaria (INTA) Mendoza, San Martín 3853,

Luján de Cuyo, Mendoza, Argentina

${ }^{6}$ Department of Plant and Soil Sciences, University of Delaware, Newark, DE 19716, USA

${ }^{7}$ Laboratorio de Investigación en Suelos, Aguas y Bosques (LISAB), Departamento de Silvicultura, Facultad de

Ciencias Forestales, Universidad de Concepción, Victoria 631, Concepción, Chile

${ }^{8}$ Departamento de Ciencias Vegetales, Facultad de Agronomía e Ingeniería Forestal, Pontificia Universidad Católica de Chile, Santiago, Chile

${ }^{9}$ Departamento de Química Inorgánica, Facultad de Química y de Farmacia, Pontificia Universidad Católica de Chile, Vicuña Mackenna 4860, Santiago, Chile

${ }^{10}$ Centro para el Desarrollo de la Nanociencia y la Nanotecnología (CEDENNA),

Av. L.B. O'Higgins 3363, Santiago, 7254758, Chile

${ }^{11}$ Center of Applied Ecology and Sustainability, Pontificia Universidad Católica de Chile, Santiago, Chile

${ }^{12}$ EcoLab UMR5245, University of Toulouse, CNRS, INP, Toulouse, France

${ }^{13}$ Departamento de Suelos y Recursos Naturales, Universidad de Concepción, Campus Chillán, Vicente Méndez 595, Chillán, Chile

${ }^{14}$ Isotope Bioscience Laboratory, Ghent University, Ghent, Belgium

${ }^{15}$ Facultad de Ciencias de la Salud, Universidad Arturo Prat, Av. Arturo Prat 2120, Iquique, Chile

${ }^{16}$ Food and Agriculture Organization of the United Nations (FAO), Regional Office for Latin America and the Caribbean, Dag Hammarskjöld, Vitacura, Chile

${ }^{17}$ Escuela de Ingeniería Bioquímica, Pontificia Universidad Católica de Valparaíso, Av. Brasil 2185, Valparaíso, Chile

${ }^{18}$ Aix-Marseille University, Université de Toulon, CNRS, IRD, MIO, UM 110, Marseille, France

${ }^{19}$ Scientific and Technological Bioresource Nucleus, Universidad de La Frontera, Temuco, Chile

${ }^{20}$ Instituto de Investigaciones Agropecuarias, INIA La Platina, Casilla 439, Correo 3, Santiago, Chile 
${ }^{21}$ Departamento de Ciencias Agropecuarias y Acuícolas Núcleo de Investigación en Producción Alimentaria, Universidad Católica de Temuco, Casilla 15-D, Temuco, Chile

${ }^{22}$ Soil Resources, ETH Zurich, Zurich, Switzerland

${ }^{23}$ Facultad de Química y Biología, Universidad de Santiago de Chile, Av. B. O’Higgins 3363, Santiago, Chile

${ }^{24}$ Ministerio del Medio Ambiente, San Martín 73, Santiago, Chile

${ }^{25}$ Corporación Nacional Forestal (CONAF), Paseo Bulnes 285, Santiago, Chile

${ }^{26}$ Facultad de Ciencias Forestales y Conservación de la Naturaleza, Universidad de Chile,

Santa Rosa 11315, La Pintana, Chile

${ }^{27}$ Instituto de Investigaciones Agropecuarias, INIA Intihuasi, Apartado Postal 36/B, La Serena, Chile

${ }^{28}$ Centro de Información de Recursos Naturales (CIREN), Santiago, Chile

${ }^{29}$ Laboratorio de Invasiones Biológicas (LIB), Facultad de Ciencias Forestales, Universidad de Concepción, Concepción, Chile

${ }^{30}$ Departamento de Ciencias Ambientales y Recursos Naturales Renovables, Facultad de Ciencias

Agronómicas, Universidad de Chile, Santa Rosa 11315, La Pintana, Chile

${ }^{31}$ Instituto de Investigaciones Agropecuarias, INIA Kampenaike, Punta Arenas, Chile

${ }^{32}$ ONG Suelo Sustentable, Santiago, Chile

${ }^{33}$ Edáfica, Santiago, Chile

${ }^{34}$ Oficina Regional de la FAO para América Latina y el Caribe, Bogotá, Colombia

${ }^{35}$ Instituto de Investigaciones Agropecuarias, INIA La Cruz, Chorrillos 86, La Cruz, Chile

${ }^{36}$ Instituto de Investigaciones Agropecuarias, INIA Quilamapu, Av. Vicente Méndez 515, Chillán, Chile

${ }^{37}$ Departamento de Ciencias Agropecuarias y Acuícolas, Universidad de Magallanes, Av. Bulnes 01855, Punta Arenas, Chile

${ }^{38}$ Oficina de Estudios y Políticas Agrarias (ODEPA), Ministerio de Agricultura, Teatinos 40, Santiago, Chile

${ }^{39}$ United Nations Convention to Combat Desertification, Regional Coordination Unit for Latin America and the Caribbean, CELADE, Dag Hammarskjöld 3477, Vitacura, Chile

${ }^{40}$ Instituto de Ingeniería Agraria y Suelos, Facultad de Ciencias Agrarias, Universidad Austral, Valdivia, Chile

${ }^{41}$ Instituto de Ecología y Biodiversidad, Av. Libertador Bernardo O'Higgins 340, Santiago, Chile

Correspondence: Marco Pfeiffer (mpfeiffer@uchile.cl)

Received: 5 September 2019 - Discussion started: 14 October 2019

Revised: 13 January 2020 - Accepted: 16 January 2020 - Published: 26 February 2020

Abstract. A critical aspect of predicting soil organic carbon (SOC) concentrations is the lack of available soil information; where information on soil characteristics is available, it is usually focused on regions of high agricultural interest. To date, in Chile, a large proportion of the SOC data have been collected in areas of intensive agricultural or forestry use; however, vast areas beyond these forms of land use have few or no soil data available.

Here we present a new SOC database for the country, which is the result of an unprecedented national effort under the framework of the Global Soil Partnership. This partnership has helped build the largest database of SOC to date in Chile, named the Chilean Soil Organic Carbon database (CHLSOC), comprising 13612 data points compiled from numerous sources, including unpublished and difficult-to-access data. The database will allow users to fill spatial gaps where no SOC estimates were publicly available previously. Presented values of SOC range from $6 \times 10^{-5} \%$ to $83.3 \%$, reflecting the variety of ecosystems that exist in Chile.

The database has the potential to inform and test current models that predict SOC stocks and dynamics at larger spatial scales, thus enabling benefits from the richness of geochemical, topographic and climatic variability in Chile.

The database is freely available to registered users at https://doi.org/10.17605/OSF.IO/NMYS3 (Pfeiffer et al., 2019b) under the Creative Commons Attribution 4.0 International Public License. 


\section{Introduction}

Soil organic carbon (SOC) stocks play a vital role in the global carbon (C) cycle and make up nearly two-thirds of the total terrestrial carbon pool (Eswaran, 2000; Sarmiento and Gruber, 2002). Therefore, knowledge of the contents and dynamics of SOC stocks is essential for estimating trends in the evolution of atmospheric carbon dioxide $\left(\mathrm{CO}_{2}\right)$ to be used as an input and applied to models of global climate change (Jones et al., 2005; Davidson and Janssens, 2006). However, predictions of SOC stocks vary widely due to the limited availability of soil data for remote regions and existing soil datasets being biased towards highly managed forest and agroecosystems (Duarte-Guardia et al., 2018). Chile is not exempt from these difficulties, having many of its publicly available soil and SOC data focused on intensively cultivated central regions (Padarian et al., 2012, 2017). In fact, vast areas of the country are situated in the high Andean mountains, the hyperarid Atacama Desert or the inaccessible Magellanic moorland of the Patagonian fjords, for which very few soil data are available. These areas are of particular interest for SOC dynamics and stock predictions as they represent the extreme ends of a huge latitudinal climate gradient, from Earth's driest extreme in the north (Atacama Desert) to the very humid conditions of the Patagonian Pacific margin, all flanked by the second-highest mountain range in the world (Garreaud et al., 2009; Ewing et al., 2008; Loisel and $\mathrm{Yu}, 2013)$.

Access to spatially explicit, consistent and reliable soil data is essential to model and map the status of soil resources globally to an increasingly detailed resolution in order to respond and assess global issues (Arrouays et al., 2014; FAO, 2015; Hengl et al., 2014; Omuto et al., 2013). Furthermore, soil datasets are one of the most important inputs for Earth system models (ESMs) to address, for example, the importance of terrestrial sinks and sources of greenhouse gases (Dai et al., 2019; Luo et al., 2016). At the same time, soils in ESMs are one of the largest sources of uncertainty (Dai et al., 2019). Hence, in recent years, there has been a growing effort to improve access to and quality of soil datasets, a key goal of the Global Soil Partnership Pillar 4 Implementation Plan sponsored by the Food and Agriculture Organization of the United Nations (Batjes et al., 2017; Omuto et al., 2013). Efforts to increase access to harmonized soil products containing comparable and consistent datasets, including soil carbon, are highly valuable and appreciated by an increasing number of users (Arora et al., 2013; Baritz et al., 2014; Batjes et al., 2017; Hendriks et al., 2016; Jones and Thornton, 2015; Luo et al., 2016; Maire et al., 2015).

In an unprecedented national effort, between May 2018 and April 2019, a group of professionals from 39 public and private institutions joined together to build the largest (to date) Chilean SOC database (CHLSOC). The database was compiled from varied data sources including soil surveys, publications, private reports, unpublished research data, and cryptic documents unknown to the public and often difficult to access. This work resulted in a harmonized database of 13612 points, which is a great improvement considering that previously up-to-date harmonized data on SOC for Chile included 45 points in WoSIS (Batjes et al., 2017).

The entire CHLSOC database (13612 data points from 25 sources; summarized in Table 1) is freely available for registered users to download at https://doi.org/10.17605/OSF.IO/NMYS3 (Pfeiffer et al., 2019b). This joint effort has resulted in a comprehensive Chilean soil database that is available to the international community for analysis, exchange and interpretation.

\section{Soil data harmonization}

\subsection{Database sources}

In order to fill the gaps in the current data, 889 soil profiles and 12723 topsoil samples from all over Chile (Table 2) were gathered, curated and harmonized. Of this information, $89 \%$ had previously been unpublished or unavailable to the national and global scientific community. The resultant soil information was from all of the administrative regions and 16 out of 17 ecological zones of Chile (Fig. 1; Table 3).

Data compiled from the literature are referenced in Table 1 . Sources include legacy soil surveys, environmental assessment reports, research papers, private reports, theses and unpublished data provided by researchers. The minimum requirements for inclusion in the database were geographiccoordinate information, records of soil horizon depth and soil organic carbon content (or organic matter content). Other soil variables, such as bulk density, texture and/or coarse fragments, sampling depth, sampling year, and measurement methods, were included where available. Approximately $20 \%$ of horizon samples included information on bulk density (BLD) measured using the clod or the core (cylinder) method, and only 382 horizons $(<3 \%)$ included information about coarse fragments (CRF).

The resulting database (summarized in Table 1) includes datasets of variable size, source and composition. Unpublished data sources are referenced in the database to the coauthor and group who provided the data. Examples of unpublished data sources are shown in Table 1 and include those of the Oficina de Estudios y Políticas Agrarias (ODEPA) with 782 points provided by José Ramirez, Methanobase (Table 1), corresponding to surface samples $(0-25 \mathrm{~cm})$ from the Magallanes Region collected in 2016 and provided by Lea Cabrol and Maialen Barret (Table 3). A further 51 data points from the Environmental Impact Assessment System (SEIA) were included from mostly underrepresented areas, such as the Andes and the Atacama Desert.

The largest contributor to CHLSOC (9935 data points) was the SOC dataset of the Agricultural and Livestock Service (SAG by its Spanish abbreviation). The data were comprised of SOC obtained from the first $20 \mathrm{~cm}$ of soil by auger 
Table 1. Database sources used in this compilation.

\begin{tabular}{|c|c|c|c|c|}
\hline Source & Samples & SOC method & BLD method & References \\
\hline Biester & 3 & DC & Core & Biester et al. (2003) \\
\hline CIREN & 540 & WO & Clod & CIREN (1996a, b, 1997a, b, 1999, 2002, 2003, 2005a, b, 2007) \\
\hline Doetterl & 22 & DC & Core & Doetterl et al. (2015) \\
\hline EarthShape & 16 & DC & Core & Bernhard et al. (2018) \\
\hline Filipová & 46 & WO & Core & Filipová et al. (2010) \\
\hline Holdgate & 33 & DC & NA & Holdgate $(1961)$ \\
\hline INIA & 1663 & WO & Clod; NA & $\begin{array}{l}\text { Hepp and Stolpe (2014); Besoain et al. (2000); Corradini et al. (2019, } \\
\text { 2017); Fabio Corradini (unpublished data); Carlos Ovalle, INIA, } \\
\text { (unpublished data); Panichini et al. (2012, 2017); Marco Pfeiffer, } \\
\text { Jorge Ivelic-Sáez, Susana Valle (unpublished data) }\end{array}$ \\
\hline McCulloch & 2 & WO & Clod & McCulloch and Davies (2001) \\
\hline Methanobase & 37 & DC & NA & Lea Cabrol and Maialen Barret (unpublished data) \\
\hline Mörchen & 12 & DC & Excavation & Mörchen et al. (2019) \\
\hline ODEPA & 782 & WO & NA & José Ramirez (unpublished data) \\
\hline PUC & 24 & WO & Clod; Core & Eduardo Arellano (unpublished data) \\
\hline Quade & 16 & DC & NA & Quade et al. (2007) \\
\hline SAG & 9935 & WO & NA & $\begin{array}{l}\text { Andrés Gomez (unpublished data); Rodrigo Osorio and Nelson Busta- } \\
\text { mante (unpublished data) }\end{array}$ \\
\hline Schuller & 14 & WO & Core & Schuller et al. (2004) \\
\hline SEIA & 51 & WO & Clod & Nicolás Riveras (unpublished data) \\
\hline $\mathrm{UACH}$ & 3 & WO & Clod; Core & $\begin{array}{l}\text { Gerding and Thiers (2002); Marco Pfeiffer, Jorge Ivelic-Sáez and Su- } \\
\text { sana Valle (unpublished data) }\end{array}$ \\
\hline UAP & 85 & WO & Clod & $\begin{array}{l}\text { Margarita Briceño (unpublished data); Delatorre et al. (2008); } \\
\text { Ehleringer et al. (1992) }\end{array}$ \\
\hline $\mathrm{UCB}$ & 8 & $\mathrm{DC} ; \mathrm{WO}$ & Clod & $\begin{array}{l}\text { Ewing et al. (2006, 2008); Finstad et al. (2018); Pfeiffer et al. (2019a); } \\
\text { Marco Pfeiffer (unpublished data); Marco Pfeiffer, Jorge Ivelic-Sáez } \\
\text { and Susana Valle (unpublished data) }\end{array}$ \\
\hline UChile & 198 & WO & Clod; Core; NA & $\begin{array}{l}\text { Norambuena (2000); Pfeiffer et al. (2012); Manuel Casanova } \\
\text { and Osvaldo Salazar (unpublished data); Fuentes et al. (2014); } \\
\text { Juan Pablo Fuentes (unpublished data); Mauricio Galleguillos (unpub- } \\
\text { lished data); Kirberg (2014); Martínez et al. (2017); Lwando Mashal- } \\
\text { aba (unpublished data); Jorge Pérez-Quezada and Mauricio Galleguil- } \\
\text { los (unpublished data); Seguel et al. (2015); Oscar Seguel (unpublished } \\
\text { data); Soto et al. (2015) }\end{array}$ \\
\hline UCT & 5 & WO & Core & $\begin{array}{l}\text { Curaqueo et al. (2010, 2011, 2014); Gustavo Curaqueo (unpublished } \\
\text { data) }\end{array}$ \\
\hline UDEC & 86 & $\mathrm{DC} ; \mathrm{WO}$ & Core; NA & $\begin{array}{l}\text { Hepp and Stolpe (2014); Felipe Aburto (unpublished data); Erick Zagal, } \\
\text { Cristina Muñoz and Sebastian Doetterl (unpublished data) }\end{array}$ \\
\hline UFRO & 16 & WO & NA & Garrido and Matus (2012) \\
\hline UMAG & 11 & $\mathrm{DC}$ & Core & Radic et al. (2013) \\
\hline Ziolkowski & 4 & DC & NA & Ziolkowski et al. (2013) \\
\hline
\end{tabular}

BLD: bulk density; WO: wet oxidation; DC: dry combustion; NA: data not provided; CIREN: Centro de Información de Recursos Naturales; INIA: Instituto de Investigaciones Agropecuarias; ODEPA: Oficina de Estudios y Políticas Agrarias; PUC: Pontificia Universidad Católica de Chile; SAG: Servicio Agrícola y Ganadero; SEIA: Sistema de Evaluación de Impacto Ambiental; UACH: Universidad Austral de Chile; UAP: Universidad Arturo Prat; UCB: University of California Berkeley; UChile: Universidad de Chile; UCT: Universidad Católica de Temuco; UDEC: Universidad de Concepción; UFRO: Universidad de la Frontera; UMAG: Universidad de Magallanes.

or excavation methods sampled by beneficiaries (farmers) of the SAG subsidy program.

Another important data contributor was the legacy soil survey data compiled by the Centro de Información de Recursos Naturales (CIREN), reported as regional soil surveys that were carried out from the 1960s up to 2007. In total, CIREN compiled 37 soil surveys, totaling 540 data points over $177500 \mathrm{~km}^{2}$ (equal to about $24.5 \%$ of the total Chilean territory), many of which are already compilations of former studies originally not referenced by CIREN (CIREN, 1996a, b, 1997a, b, 1999, 2002, 2003, 2005a, b, 2007).

\subsection{Data harmonization processing and caveats}

The assembled data were sampled over several decades and compiled by different authors and institutions. We would like to mention the following warnings to the data users: first, 
Table 2. Summary of the soil points included in the Chilean Soil Organic Carbon database (CHLSOC).

\begin{tabular}{lr}
\hline Variable & Value \\
\hline Number of profiles & 889 \\
Number of topsoil samples & 12723 \\
SOC measurements & 16884 \\
SOC using wet-oxidation method & 16363 \\
SOC using dry-combustion method & 521 \\
Minimum SOC $(\%)$ & $6 \times 10^{-5}$ \\
Maximum SOC $(\%)$ & 83.30 \\
BLD measurements & 2757 \\
BLD using core method & 533 \\
BLD using clod method & 2224 \\
Minimum BLD $\left(\mathrm{g} \mathrm{cm}^{-3}\right)$ & 0.03 \\
Maximum BLD $\left(\mathrm{g} \mathrm{cm}{ }^{-3}\right)$ & 2.38 \\
CRF measurements & 382 \\
Minimum CRF $(\%)$ & 0.00 \\
Maximum CRF $(\%)$ & 78.31 \\
\hline
\end{tabular}

SOC: soil organic carbon; BLD: bulk density; CRF: coarse fragments; topsoil considers points with surface samples only $(<30 \mathrm{~cm})$.

for some data points it was not possible to find or verify the original data source. Second, a potential source of uncertainty may be the analytical method employed for analysis; for most samples (97\%), SOC content was analyzed using the wet-oxidation method, and a small number were analyzed by total combustion (CN elemental analyzer). Discrepancies in SOC results between combustion methods have identified wet combustion as a less reliable assessment method for SOC, as it tends to underestimate organic carbon at higher SOC contents (Kumar et al., 2019) and potentially overestimates it in highly reduced soils (Chatterjee et al., 2009). This issue has not been addressed in Chile to date. The recommended methods for SOC determination are currently wet oxidation and loss on ignition; however, dry combustion is a more accurate alternative (Sadzawka et al., 2006). Future data collection initiatives should stress consistent analytical procedures as a revision of local standards is urgently required. Finally, a possible source of bias in data from SAG is the fact that samples were taken by farmers following SAG guidelines where a composite sampling is taken for each parcel.

\section{The spatiotemporal distribution of the Chilean SOC database}

\subsection{Spatial distribution}

To date, CHLSOC is the most complete data compilation for mainland Chile, comprising 13612 points, a great improvement in comparison with former databases used in Chile for SOC assessments. For example, national SOC mapping studies (Padarian et al., 2017; Reyes Rojas et al., 2018) were based almost exclusively on CIREN data (540 points). CHLSOC can be used to show the influence of soil, vegetation and climatic conditions on SOC concentrations. Table 3 shows the number of data compiled in this work, by vegetation formation. It is important to note that the scheme of Luebert and Pliscoff (2006) corresponds to the potential vegetation belts that originally occupied the territory and does not necessarily reflect current land use. We refer to vegetation formations as "ecosystems" as this is a more common term and to avoid further specific disciplinary discussion, which is outside the scope of this work. In order to represent each ecosystem (by vegetation formation) in CHLSOC, the database is based on the number of data points divided by the total coverage of the ecosystem in Chile.

More than two thirds $(85.73 \%)$ of the data are sampled from a concentrated area (25\% of the total country area) found in the following four ecosystems: deciduous forest, broad-leaved forest, sclerophyllous forest and thorny forest. The first two ecosystems are located in the northern section of the temperate macrobioclimatic zone and the second two in the southern section of the Mediterranean macrobioclimatic zone (Moreira-Muñoz, 2011). These ecosystems are characterized by a combination of benign climate, high-quality soils and water availability (for irrigation), resulting in a long history of agricultural activity and human settlement (Armesto et al., 2010). For this reason, these areas have experienced the highest land use conversion to agriculture, forestry and urban use in the country (Echeverría et al., 2006; Schulz et al., 2010; Arroyo et al., 2008). Deciduous forests ( $14.7 \%$ of the country) are the most represented, with $52.14 \%$ of the data points collected in CHLSOC located between latitudes 35 and $41^{\circ} \mathrm{S}$ (Fig. 1).

The second-largest pool of data $(8.6 \%$ of the total data compiled in this work) is for evergreen forest, steppe and grassland (Table 3), which comprise $10.3 \%$ of the country's area. These ecosystems are located between 41 and $53^{\circ} \mathrm{S}$ in the temperate macrobioclimate (Moreira-Muñoz, 2011), a thermally homogeneous territory with a considerable precipitation gradient that can reach several meters of mean annual precipitation on its western section, along the Pacific coast (Garreaud et al., 2009). These areas contain vast sections of pristine forest, with only $8 \%$ of the land being converted to other land use (Pliscoff and Fuentes-Castillo, 2011). Most of the data collected here correspond to the eastern section of the administrative region of Aysén in Patagonia. The relatively high representation of these ecosystems in the database can be attributed to (i) the intense agricultural use of the northern section of the evergreen forest and (ii) an unprecedented effort in soil sampling in the Aysén Region (43.5$49^{\circ} \mathrm{S}$ ) by SAG and the Agricultural Research Institute (INIA by its Spanish acronym; Table 1; Hepp and Stolpe, 2014).

Arguably the most important ecosystem in terms of SOC stocks for Chile is that of the moorlands, which comprise a large area located on the Pacific coast of Patagonia where the landscape is fragmented into fjords and small islands (be- 
Table 3. Distribution of SOC data points per ecosystem (vegetation formation) according to Luebert and Pliscoff (2006).

\begin{tabular}{|c|c|c|c|c|c|c|c|}
\hline Vegetation formation & Data points & Country area $(\%)$ & $\begin{array}{r}\text { Representativeness index } \\
\text { (points per } \% \text { area) }\end{array}$ & $\begin{array}{r}\text { SOC } \\
\text { (mean) }\end{array}$ & $\begin{array}{r}\mathrm{SOC} \\
(\mathrm{min})\end{array}$ & $\begin{array}{r}\text { SOC } \\
(\max )\end{array}$ & $\begin{array}{l}\mathrm{SOC} \\
(\mathrm{SD})\end{array}$ \\
\hline Deciduous forest & 7098 & 14.70 & 482.86 & 8.01 & 0.00 & 83.30 & 3.91 \\
\hline Sclerophyllous forest & 2544 & 5.20 & 489.23 & 2.66 & 0.00 & 15.61 & 1.87 \\
\hline Thorny forest & 1392 & 2.80 & 497.14 & 1.90 & 0.00 & 20.70 & 1.50 \\
\hline Broad-leaved forest & 645 & 1.90 & 339.47 & 12.02 & 0.15 & 25.75 & 5.11 \\
\hline Coniferous forest & 94 & 2.30 & 40.87 & 6.02 & 0.10 & 25.00 & 3.40 \\
\hline Evergreen forest & 828 & 6.90 & 120.00 & 11.70 & 0.01 & 81.19 & 7.89 \\
\hline Desert & 47 & 7.70 & 6.10 & 1.63 & 0.00 & 15.00 & 1.84 \\
\hline Steppe and grassland & 343 & 3.40 & 100.88 & 6.02 & 0.00 & 56.70 & 10.87 \\
\hline Herbaceous alpine vegetation & 2 & 2.40 & 0.83 & 5.11 & 5.01 & 5.20 & 0.13 \\
\hline Evergreen shrubland & 0 & 0.30 & 0.00 & - & - & - & - \\
\hline Alpine dwarf scrub & 100 & 13.80 & 7.25 & 1.42 & 0.01 & 41.60 & 6.09 \\
\hline Low desert scrub & 20 & 8.70 & 2.30 & 0.92 & 0.02 & 25.40 & 2.94 \\
\hline Deciduous shrubland & 2 & 2.30 & 0.87 & 4.47 & 2.20 & 10.19 & 3.19 \\
\hline Desertic scrub & 231 & 9.50 & 24.32 & 1.19 & 0.00 & 22.60 & 1.69 \\
\hline Thorny shrubland & 17 & 0.30 & 56.67 & 1.11 & 0.20 & 2.49 & 0.61 \\
\hline Arborescent shrubland & 158 & 1.00 & 158.00 & 5.26 & 0.08 & 42.50 & 5.70 \\
\hline Moorland & 20 & 9.10 & 2.20 & 43.86 & 1.74 & 57.71 & 21.10 \\
\hline
\end{tabular}

Percentages of surface area and English names for vegetation formations were taken from Pliscoff and Fuentes-Castillo (2011).

tween 44 and $\left.55^{\circ} \mathrm{S}\right)$. The moorlands cover a significant section $(9.1 \%)$ of the country's area and are probably the largest soil carbon reservoir in Chile, with an almost continuous carpet of thick peat bog to a depth of $5 \mathrm{~m}$ in some places (Loisel and Yu, 2013; Minasny et al., 2019). Despite the importance of moorland soils, most of our knowledge of this ecosystem comes from the northern and eastern borders, whereas there is limited information about peat soils in remote areas of the western fjords (20 observations in this database).

The Atacama Desert section of Chile (Table 3; desert, low desert scrub and desertic scrub) comprises $2.18 \%$ of the CHLSOC database but corresponds to $6 \%$ of the country's area. However, the number of data points compiled for this region (298) constitutes a great improvement compared with previous national work on SOC for the Atacama Desert, which only included 3 points (Padarian et al., 2017).

The scarce SOC information for this region may be due to the extreme aridity of the region, low biological activity and low SOC accumulation (McKay et al., 2003). Vegetation is restricted to a narrow belt along the coast that receives water from fog, deep valleys that cross the desert and the western flank of the Andes (Moreira-Muñoz, 2011).

Regions of high altitude and mountainous areas comprise 102 data points $(0.74 \%$ of the database) representing $16.2 \%$ of the country's area. Two characteristic alpine vegetation formations exist in the Chilean Andes between 18 and $38^{\circ} \mathrm{S}$ (Fig. 1) that comprise herbaceous alpine vegetation and alpine dwarf scrub. Most of the data are concentrated on the lower part (alpine dwarf scrub), while virtually no soil data are available for the higher section of the Andes (above $3000 \mathrm{~m}$ a.s.1.). The scarcity of soil data for this region means that assessment of the impact of climate change on soil C stocks is uncertain as large quantities of SOC are stored in this ecosystem (Bockheim and Munroe, 2014).

Few data are available for the coniferous forest, deciduous shrubland, thorny shrubland and arborescent shrubland areas of vegetation (Table 3) located in areas of low forestry or agricultural interest, but these areas comprise less than $2.5 \%$ of the country.

In summary, the data we have compiled demonstrate the imbalance between areas of agricultural and forestry interest and areas beyond those land uses. Three areas of high value in terms of ecological, scientific and ecosystem services nationwide (and worldwide) are underrepresented in terms of soil data: the high Andes, the Atacama Desert and western Patagonia. Government efforts to develop soil surveys in these regions should be promoted urgently. In particular, a SOC inventory of western Patagonia is essential to properly assess the national stock of SOC and the potential to include this area in carbon offset programs.

\subsection{Temporal distribution}

The date of sample collection is provided in more than $90 \%$ of the included data (12318 data points). The majority of points were sampled in 2006 and between 2010 and 2018 (Fig. 2). The high number of data from the last decade enables users to estimate modern carbon in Chilean soils. Most of the data that report the year in which they were sampled are concentrated in a short timeframe and mainly correspond to the SAG database (2010-2018) and to sampling efforts re- 


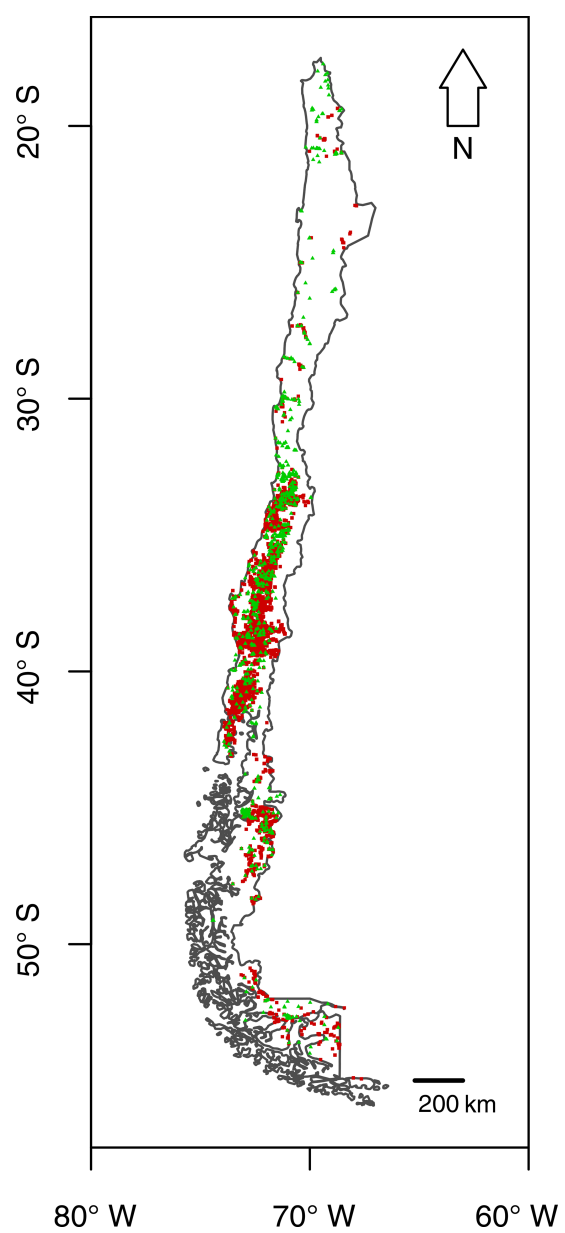

Figure 1. Spatial distribution of soil data points compiled in this work. Green triangles are soil profiles, and red squares are topsoil samples (up to $30 \mathrm{~cm}$ ).

lated to research projects such as ODEPA in 2006 and INIA (mainly 2015-2018).

Data from CIREN (Table 1) did not report a sampling date. However, as they consist of a compilation of known former soil surveys, we can limit the period in which samples were collected and analyzed to the period between 1970 and 2007. The oldest data points correspond to those collected by Holdgate (1961) in the western Patagonian fjords in 1959.

\section{Data availability}

Data are available at: https://doi.org/10.17605/OSF.IO/ NMYS3 (Pfeiffer et al., 2019b); the data are represented by a code defining the soil name; soils from the CIREN data source are identified by a three-letter code corresponding to the soil series, and data from 10 other sources are identified by the site or author name. Geographical coordinates are according to UTM WGS 84.

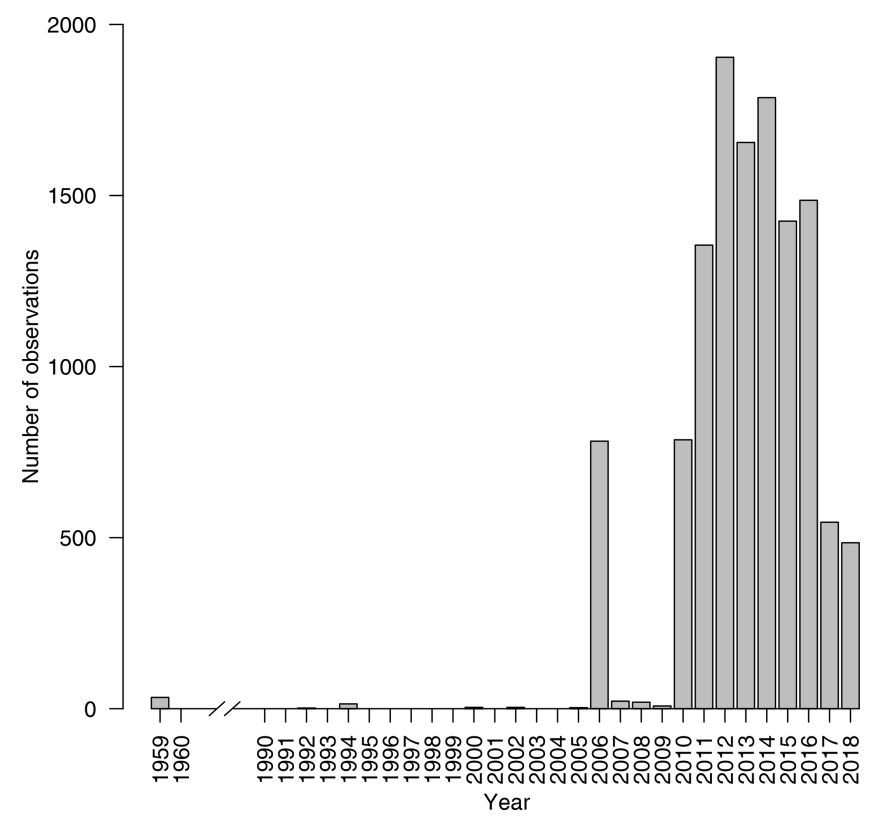

Figure 2. Temporal distribution of the samples included in CHLSOC.

\section{Conclusions}

The process of generating this database was a distributed data collection effort, which is a step forward under the efforts of the GlobalSoilMap.net project and the guidelines of the FAO Global Soil Partnership. The database presented here increases the public availability of SOC data for Chile 10fold thanks to a joint effort of dozens of researchers and institutions. A high proportion of this database, 89\% (12 125 data points), consists of unpublished data that have now been made available. CHLSOC now contains a valuable SOC representation of a mosaic of ecosystems in Chile which represents one of Earth's most extreme climate gradients. However, there are still big differences in the number of data obtained from managed (agro)ecosystems and natural systems in areas of low population density. We would like to stress the urgency of generating a discussion at a national level regarding the need for a comprehensive soil survey program to increase the sampling in these underrepresented areas. Moreover, to include more data in the next versions of CHLSOC, future official CIREN soil surveys in Chile and other datasets should be encouraged to report holistic metadata covering sampling designs, locations, sampling dates and analysis methods. 


\section{Appendix A}

Table A1. Naming conventions and descriptions of variables provided in the Chilean Soil Organic Carbon database (CHLSOC).

\begin{tabular}{lll}
\hline Variable & Unit & Description \\
\hline ProfileID & - & Soil profile identification \\
top & $\mathrm{cm}$ & Soil horizon upper border \\
bottom & $\mathrm{cm}$ & Soil horizon lower border \\
bd & $\mathrm{g} \mathrm{cm}^{-3}$ & Bulk density \\
oc & $\%$ & Organic carbon \\
$\mathrm{crf}$ & $\%$ & Coarse fragments \\
long & decimal degrees & Longitude \\
lat & decimal degrees & Latitude \\
year & - & Year of data collection \\
oc $m$ method & - & Organic carbon method \\
bd & - & Bulk density method \\
reference & - & Source of data \\
\hline
\end{tabular}


Author contributions. MP, GFO, MG, RO, NB, JB, MF, GG, AG, JM, JR, CR, IS and SB designed the framework to produce the database. The paper was written by MP and JP with contributions from all other authors, who reviewed and provided input on the paper.

Competing interests. The authors declare that they have no conflict of interest.

Acknowledgements. The following authors of unpublished data acknowledge funding from the following sources: Felipe Aburto, Fondecyt de Iniciación, grant no. 11160372, and Convenio CONAF-UDeC 2015 Perturbaciones Araucaria; Maialent Barret and Lea Cabrol, ERANet-LAC joint program, grant no. ELAC2014/DCC-0092; Erick Zagal and Cristina Muñoz, Proyecto Fondecyt, grant no. 1161492. Federico Olmedo and Mario Guevara were supported by the Global Soil Partnership and the South America Soil Partnership, both sponsored by the Food and Agriculture Organization of the United Nations (FAO).

Financial support. There was no financial support for the publication of this paper.

Review statement. This paper was edited by Giulio G. R. Iovine and reviewed by Sergey Zimov and three anonymous referees.

\section{References}

Armesto, J. J., Manuschevich, D., Mora, A., Smith-Ramirez, C., Rozzi, R., Abarzúa, A. M., and Marquet, P. A.: From the Holocene to the Anthropocene: A historical framework for land cover change in southwestern South America in the past 15,000 years, Land Use Policy, 27, 148-160, 2010.

Arora, V. K., Boer, G. J., Friedlingstein, P., Eby, M., Jones, C. D., Christian, J. R., Bonan, G., Bopp, L., Brovkin, V., Cadule, P., Hajima, T., Ilyina, T., Lindsay, K., Tjiputra, J. F., and Wu, T.: Carbon-concentration and carbon-climate feedbacks in CMIP5 Earth system models, J. Climate, 26, 5289-5314, 2013.

Arrouays, D., Grundy, M. G., Hartemink, A. E., Hempel, J. W., Heuvelink, G. B., Hong, S. Y., Lagacherie, P., Lelyk, G., McBratney, A. B., McKenzie, N. J., Mendonca-Santos, M. d. L., Minasny, B., Montanarella, L., Odeh, I. O. A., Sanchez, P. A., Thompson, J. A., and Zhang, G.-L.: GlobalSoilMap: Toward a fine-resolution global grid of soil properties, Adv. Agron., 125, 93-134, 2014.

Arroyo, M. T., Marquet, P., Marticorena, C., Simonetti, J., Cavieres, L., Squeo, F., Rozzi, R., and Massardo, F.: El hotspot chileno, prioridad mundial para la conservación, Biodiversidad de Chile, patrimonio y desafíos, 90-93, 2008.

Baritz, R., Erdogan, H., Fujii, K., Takata, Y., Nocita, M., Bussian, B., Batjes, N., Hempel, J., Wilson, P., and Vargas, R.: Harmonization of methods, measurements and indicators for the sustainable management and protection of soil resources, Food and Agricul- ture Organization (FAO) Annual Plenary Assembly, 2nd Plenary, Rome, Italy, 22-24 July, 2014.

Batjes, N. H., Ribeiro, E., van Oostrum, A., Leenaars, J., Hengl, T., and Mendes de Jesus, J.: WoSIS: providing standardised soil profile data for the world, Earth Syst. Sci. Data, 9, 1-14, https://doi.org/10.5194/essd-9-1-2017, 2017.

Bernhard, N., Moskwa, L.-M., Schmidt, K., Oeser, R. A., Aburto, F., Bader, M. Y., Baumann, K., von Blanckenburg, F., Boy, J., van den Brink, L., Brucker, E., Büdel, B., Canessa, R., Dippold, M. A., Ehlers, T. A., Fuentes, J. P., Godoy, R., Jung, P., Karsten, U., Köster, M., Kuzyakov, Y., Leinweber, P., Neidhardt, H., Matus, F., Mueller, C. W., Oelmann, Y., Oses, R., Osses, P., Paulino, L., Samolov, E., Schaller, M., Schmid, M., Spielvogel, S., Spohn, M., Stock, S., Stroncik, N., Tielbörger, K., Übernickel, K., Scholten, T., Seguel, O., Wagner, D., and Kühn, P.: Pedogenic and microbial interrelations to regional climate and local topography: New insights from a climate gradient (arid to humid) along the Coastal Cordillera of Chile, Catena, 170, 335355, 2018.

Besoain, M., Peralta, P., and Massaro, M.: Mineralogy and origin of some volcanic ash soils of continental Chiloé, Chile, Agr. Tec., 60, 127-153, 2000.

Biester, H., Martinez-Cortizas, A., Birkenstock, S., and Kilian, R.: Effect of peat decomposition and mass loss on historic mercury records in peat bogs from Patagonia, Environ. Sci. Technol., 37 , 32-39, 2003.

Bockheim, J. G. and Munroe, J. S.: Organic carbon pools and genesis of alpine soils with permafrost: a review, Arct. Antarct. Alp. Res., 46, 987-1006, 2014.

Chatterjee, A., Lal, R., Wielopolski, L., Martin, M. Z., and Ebinger, M. H.: Evaluation of different soil carbon determination methods, Crit. Rev. Plant Sci., 28, 164-178, 2009.

CIREN: Estudio agrológico VI Región, Descripciones de Suelos, Materiales y Símbolos, Actualización 1996 (Pub. CIREN $\mathrm{N}^{\circ}$ 114/1996), 1996a.

CIREN: Estudio agrológico Región Metropolitana, Descripciones de Suelos, Materiales y Símbolos, Actualización 1996 (Pub. CIREN N 115/1996), 1996b.

CIREN: Estudio agrológico V Región, Descripciones de Suelos, Materiales y Símbolos, Actualización 1997 (Pub. CIREN $\left.\mathrm{N}^{\circ} 116 / 1997\right), 1997 \mathrm{a}$.

CIREN: Estudio agrológico VII Región, Descripciones de Suelos, Materiales y Símbolos, Actualización 1997 (Pub. CIREN $\left.\mathrm{N}^{\circ} 117 / 1997\right), 1997 \mathrm{~b}$.

CIREN: Estudio agrológico VIII Región, Descripciones de Suelos, Materiales y Símbolos, Actualización 1997 (Pub. CIREN $\mathrm{N}^{\circ}$ 121/1999), 1999.

CIREN: Estudio agrológico IX Región, Descripciones de Suelos, Materiales y Símbolos. Actualización 2002 (Pub. CIREN $\mathrm{N}^{\circ}$ 122/2002), 2002.

CIREN: Estudio agrológico X Región, Descripciones de Suelos, Materiales y Símbolos, Actualización 2003 (Pub. CIREN $\mathrm{N}^{\circ}$ 123/2003), 2003.

CIREN: Estudio agrológico IV Región, Descripciones de Suelos, Materiales y Símbolos, Actualización 2005 (Pub. CIREN $\left.\mathrm{N}^{\circ} 129 / 2005\right), 2005 \mathrm{a}$.

CIREN: Estudio agrológico XI Región, Descripciones de Suelos, Materiales y Símbolos, Actualización 2005 (Pub. CIREN $\left.\mathrm{N}^{\circ} 130 / 2005\right), 2005 \mathrm{~b}$. 
CIREN: Estudio agrológico III Región, Descripciones de Suelos, Materiales y Símbolos, Actualización 2007 (Pub. CIREN $\mathrm{N}^{\circ}$ 135/2007), 2007.

Corradini, F., Meza, F., and Calderón, R.: Trace element content in soil after a sediment-laden flood in northern Chile, J. Soil. Sediment., 17, 2500-2515, 2017.

Corradini, F., González, N., Casado, F., Rojas, V., and van der Ploeg, M.: Usefulness of an opportunistic data analysis approach to evaluate if environmental regulations aim at relevant applications, Geoderma, 351, 261-269, https://doi.org/10.1016/j.geoderma.2019.05.007, 2019.

Curaqueo, G., Acevedo, E., Cornejo, P., Seguel, A., Rubio, R., and Borie, F.: Tillage effect on soil organic matter, mycorrhizal hyphae and aggregates in a mediterranean agroecosystem, Rev. Cienc. Suelo Nutr., 10, 12-21, 2010.

Curaqueo, G., Barea, J. M., Acevedo, E., Rubio, R., Cornejo, P., and Borie, F.: Effects of different tillage system on arbuscular mycorrhizal fungal propagules and physical properties in a Mediterranean agroecosystem in central Chile, Soil Till. Res., 113, 11$18,2011$.

Curaqueo, G., Meier, S., Khan, N., Cea, M., and Navia, R.: Use of biochar on two volcanic soils: effects on soil properties and barley yield, J. Soil Sci. Plant Nut., 14, 911-924, 2014.

Dai, Y., Shangguan, W., Wei, N., Xin, Q., Yuan, H., Zhang, S., Liu, S., Lu, X., Wang, D., and Yan, F.: A review of the global soil property maps for Earth system models, SOIL, 5, 137-158, https://doi.org/10.5194/soil-5-137-2019, 2019.

Davidson, E. A. and Janssens, I. A.: Temperature sensitivity of soil carbon decomposition and feedbacks to climate change, Nature, 440, 165-173, 2006

Delatorre, J., Pinto, M., and Cardemil, L.: Effects of water stress and high temperature on photosynthetic rates of two species of Prosopis, J. Photochem. Photobio. B, 92, 67-76, 2008.

Doetterl, S., Stevens, A., Six, J., Merckx, R., Van Oost, K., Casanova, M., Casanova-Katny, A., Muñoz, C., Boudin, M., Zagal Venegas, E., and Boeckx, P.: Soil carbon storage controlled by interactions between geochemistry and climate, Nat. Geosci., 8, 780-783, 2015.

Duarte-Guardia, S., Peri, P. L., Amelung, W., Sheil, D., Laffan, S. W., Borchard, N., Bird, M. I., Dieleman, W., Pepper, D. A., Zutta, B., Jobbagy, E., Silva, L. C. R., Bonser, S. P., Berhongaray, G., Piñeiro, G., Martinez, M.-J., Cowie, A. L., and Ladd, B.: Better estimates of soil carbon from geographical data: a revised global approach, Mitigation and Adaptation Strategies for Global 30 Change, 1-18, 2018.

Echeverría, C., Coomes, D., Salas, J., Rey-Benayas, J. M., Lara, A., and Newton, A.: Rapid deforestation and fragmentation of Chilean temperate forests, Biol. Conserv., 130, 481-494, 2006.

Ehleringer, J. R., Mooney, H. A., Rundel, P. W., Evans, R. D., Palma, B., and Delatorre, J.: Lack of nitrogen cycling in the Atacama Desert, Nature, 359, 316-318, 1992.

Eswaran, H.: Global carbon stock, Global climate change and pedogenic carbonates, in: Global climate change and pedogenic carbonates, edited by: Lal, R., Kimble, J., Stewart, B. A., and Eswaran, H., CRC Press, Boca Raton, Florida 15-25, 2000.

Ewing, S., Macalady, J., Warren-Rhodes, K., McKay, C., and Amundson, R.: Changes in the soil $\mathrm{C}$ cycle at the arid-hyperarid transition in the Atacama Desert, J. Geophys. Res.-Biogeo., 113, G02S90, https://doi.org/10.1029/2007JG000495, 2008.
Ewing, S. A., Sutter, B., Owen, J., Nishiizumi, K., Sharp, W., Cliff, S. S., Perry, K., Dietrich, W., McKay, C. P., and Amundson, R.: A threshold in soil formation at Earth's arid-hyperarid transition, Geochim. Cosmochim. Ac., 70, 5293-5322, 2006.

FAO, Food and Agriculture Organization: Status of the World's Soil Resources (SWSR)-Main Report, Food and Agriculture Organization of the United Nations and Intergovernmental Technical Panel on Soils, Rome, Italy, 648 pp., 2015.

Filipová, L., Hédl, R., and Covacevich, N.: Variability of soil types in wetland meadows in the south of the Chilean Patagonia, Chil. J. Agr. Res., 70, 266-277, 2010.

Finstad, K. M., Pfeiffer, M., McNicol, G., Tuite, M., Williford, K., and Amundson, R.: A late Quaternary paleoenvironmental record in sand dunes of the northern Atacama Desert, Chile, Quaternary Res., 90, Volume 90, 127-138, https://doi.org/10.1017/qua.2018.20, 2018.

Fuentes, I., Casanova, M., Seguel, O., Nájera, F., and Salazar, O.: Morphophysical pedotransfer functions for groundwater pollution by nitrate leaching in Central Chile, Chil. J. Agr. Res., 74, 340-348, 2014.

Garreaud, R. D., Vuille, M., Compagnucci, R., and Marengo, J.: Present-day south american climate, Palaeogeogr. Palaeocl., 281, 180-195, 2009.

Garrido, E. and Matus, F.: Are organo-mineral complexes and allophane content determinant factors for the carbon level in Chilean volcanic soils?, Catena, 92, 106-112, 2012.

Gerding, V. and Thiers, O.: Caracterización de suelos bajo bosques de Nothofagus betuloides (Mirb) Blume, en Tierra del Fuego, Chile, Rev. Chil. Hist. Nat., 75, 819-833, 2002.

Hendriks, C., Stoorvogel, J., and Claessens, L.: Exploring the challenges with soil data in regional land use analysis, Agr. Syst., 144, 9-21, 2016.

Hengl, T., de Jesus, J. M., MacMillan, R. A., Batjes, N. H., Heuvelink, G. B., Ribeiro, E., Samuel-Rosa, A., Kempen, B., Leenaars, J. G., Walsh, M. G., and Ruiperez Gonzalez, M.: SoilGrids $1 \mathrm{~km}$ - global soil information based on automated mapping, PloS one, 9, e105992, https://doi.org/10.1371/journal.pone.010599, 2014.

Hepp, C. and Stolpe, N.: Caracterización y Propiedades de los Suelos de la Patagonia Occidental (Aysén), Coyhaique, Chile, 2014 (INIA Pub N 298), 161 pp., 2014.

Holdgate, M.: Vegetation and soils in the south Chilean islands, J. Ecol., 49, 559-580, 1961.

Jones, C., McConnell, C., Coleman, K., Cox, P., Falloon, P., Jenkinson, D., and Powlson, D.: Global climate change and soil carbon stocks; predictions from two contrasting models for the turnover of organic carbon in soil, Glob. Change Biol., 11, 154-166, 2005.

Jones, P. G. and Thornton, P. K.: Representative soil profiles for the Harmonized World Soil Database at different spatial resolutions for 25 agricultural modelling applications, Agr. Syst., 139, 93 99, 2015.

Kirberg, D.: Estabilización de cárcavas con enmiendas orgánicas en la Región de Coquimbo, Master Thesis, Universidad de Chile, Santiago, 82 pp., 2014.

Kumar, S., Ghotekar, Y. S., and Dadhwal, V. K.: C-equivalent correction factor for soil organic carbon inventory by wet oxidation, dry combustion and loss on ignition methods in Himalayan region, J. Earth Syst. Sci., 128, 62, https://doi.org/10.1007/s12040019-1086-9, 2019. 
Loisel, J. and Yu, Z.: Holocene peatland carbon dynamics in Patagonia, Quaternary Sci. Rev., 69, 125-141, 2013.

Luebert, F. and Pliscoff, P.: Sinopsis bioclimática y vegetacional de Chile, Editorial Universitaria, 2006.

Luo, Y., Ahlström, A., Allison, S. D., Batjes, N. H., Brovkin, V., Carvalhais, N., Chappell, A., Ciais, P., Davidson, E. A., Finzi, A., Georgiou, K., Guenet, B., Hararuk, O., Harden, J. W., He, Y., Hopkins, F., Jiang, L., Koven, C., Jackson, R. B., Jones, C. D., Lara, M. J., Liang, J., McGuire, A. D., Parton, W., Peng, C., Randerson, J. T., Salazar, A., Sierra, C. A., Smith, M. J., Tian, H., Todd-Brown, K. E. O., Torn, M., van Groenigen, K. J., Wang, Y. P., West, T. O., Wei, Y., Wieder, W. R., Xia, J., Xu, X., Xu, X., and Zhou, T.: Toward more realistic projections of soil carbon dynamics by Earth system models, Global Biogeochem. Cy., 30, 40-56, 2016.

Maire, V., Wright, I. J., Prentice, I. C., Batjes, N. H., Bhaskar, R., van Bodegom, P. M., Cornwell, W. K., Ellsworth, D., Niinemets, Ü., Ordonez, A., Reich, P. B., and Santiago, L. S.: Global effects of soil and climate on leaf photosynthetic traits and rates, Global Ecol. Biogeogr., 24, 706-717, 2015.

Martínez, I., Brunel, N., Seguel, O., Ovalle, C., and Acevedo, E.: Eficiencia del uso del agua en una rotación avena (Avena sativa)trigo (Triticum aestivum) en un suelo Alfisol degradado, Tópicos en ciencias agropecuarias, p. 60, 2017.

McCulloch, R. D. and Davies, S. J.: Late-glacial and Holocene palaeoenvironmental change in the central Strait of Magellan, southern Patagonia, Palaeogeogr. Palaeocl., 173, 143-173, 2001.

McKay, C. P., Friedmann, E. I., Gómez-Silva, B., CáceresVillanueva, L., Andersen, D. T., and Landheim, R.: Temperature and moisture conditions for life in the extreme arid region of the Atacama Desert: four years of observations including the El Nino of 1997-1998, Astrobiology, 3, 393-406, 2003.

Minasny, B., Berglund, Ö., Connolly, J., Hedley, C., de Vries, F., Gimona, A., Kempen, B., Kidd, D., Lilja, H., Malone, B., McBratney, A., Roudier, P., O’Rourke, S., Rudiyanto, Padarian, J., Poggio, L., ten Caten, A., Thompson, D., Tuve, C., Widyatmanti, W.: Digital mapping of peatlands - A critical review, Earth-Sci. Rev., 196, 102870, https://doi.org/10.1016/j.earscirev.2019.05.014, 2019.

Mörchen, R., Lehndorff, E., Diaz, F. A., Moradi, G., Bol, R., Fuentes, B., Klumpp, E., and Amelung, W.: Carbon accrual in the Atacama Desert, Global Planet. Change, 181, 102993, https://doi.org/10.1016/j.gloplacha.2019.102993, 2019.

Moreira-Muñoz, A.: Plant geography of Chile, vol. 5, Springer Science \& Business Media, 2011.

Norambuena, P.: Caracterizacion y clasificacion de algunos suelos de la provincia de Parinacota, I Region de Chile, Tesis Ingeniero Agronomo, Universidad de Chile, 2000, 30 pp., 2000.

Omuto, C., Nachtergaele, F., and Rojas, R. V.: State of the Art Report on Global and regional Soil Information: Where are we? Where to go?, Food and Agriculture Organization of the United Nations Rome, 2013.

Padarian, J., Pérez-Quezada, J., and Seguel, O.: Modelling the distribution of organic carbon in the soils of Chile, in: Proceeding of the fifth global workshop on digital soil mapping, Digital Soil assessments and beyond, Sydney, 329-333, 2012.

Padarian, J., Minasny, B., and McBratney, A.: Chile and the Chilean soil grid: a contribution to GlobalSoilMap, Geoderma Regional, 9, 17-28, 2017.
Panichini, M., Matus, F., Mora, M., Godoy, R., Bolan, N., Rumpel, C., and Borie, F.: Carbon distribution in top-and subsoil horizons of two contrasting Andisols under pasture or forest, Eur. J. Soil Sci., 63, 616-624, 2012.

Panichini, M., Neculman, R., Godoy, R., Arancibia-Miranda, N., and Matus, F.: Understanding carbon storage in volcanic soils under selectively logged temperate rainforests, Geoderma, 302, 76-88, 2017.

Pfeiffer, M., Aburto, F., Le Roux, J. P., Kemnitz, H., Sedov, S., Solleiro-Rebolledo, E., and Seguel, O.: Development of a Pleistocene calcrete over a sequence of marine terraces at Tongoy (north-central Chile) and its paleoenvironmental implications, Catena, 97, 104-118, 2012.

Pfeiffer, M., Latorre, C., Gayo, E., and Amundson, R.: Rare calcium chloride-rich soil and implications for the existence of liquid water in a hyperarid environment, Geology, 47, 163-166, https://doi.org/10.1130/G45642.1, 2019a.

Pfeiffer, M., Padarian, J., Osorio, R., Bustamante, N., Olmedo, G., Guevara, M., Aburto, F., Antilen, M., Araya, E., Arellano, E., Barret, M., Barrera, J., Boeckx, P., Briceño, M., Bunning, S., Cabrol, L., Casanova, M., Cornejo, Pablo, C. F., Curaqueo, G., Doetterl, S., Duran, P., Escudey, M., Espinoza, A., Francke, S., Fuentes, J. P., Fuentes, M., Gajardo, G., García, R., Gallaud, A., Galleguillos, M., Gomez, A., Hidalgo, M., Ivelic-Sáez, J., Mashalaba, L., Matus, F., Mora, M., Mora, J., Muñoz, C., Norambuena, P., Olivera, C., Ovalle, C., Panichini, M., Pauchard, A., Perez-Quezada, J., Radic, S., Ramirez, J., Riveras, N., Ruiz, G., Salazar, O., Salgado, I., Seguel, O., Sepúlveda, M., Sierra, C., Tapia, Y., Toledo, B., Torrico, J. M., Valle, S., Vargas, R., Wolff, M., and Zagal, E.: CHLSOC: The Chilean Soil Organic Carbon database, https://doi.org/10.17605/OSF.IO/NMYS3, 2019b.

Pliscoff, P. and Fuentes-Castillo, T.: Representativeness of terrestrial ecosystems in Chile's protected area system, Environ. Conserv., 38, 303-311, 2011.

Quade, J., Rech, J. A., Latorre, C., Betancourt, J. L., Gleeson, E., and Kalin, M. T.: Soils at the hyperarid margin: the isotopic composition of soil carbonate from the Atacama Desert, Northern Chile, Geochim. Cosmochim. Ac., 71, 3772-3795, 2007.

Radic, S., Fernandez, A., Opazo, S., McAdam, J., and Ivelic, J.: Soil bulk density from grasslands in the Magallanes Region, Chile, in: 10th International Conference of Agrophysics, Book of Abstract, Lublin, Poland, p. 105, 2013.

Reyes Rojas, L. A., Adhikari, K., and Ventura, S. J.: Projecting Soil Organic Carbon Distribution in Central Chile under Future Climate Scenarios, J. Environ. Qual., 2018.

Sadzawka, A., Carrasco, M., Grez, R., Mora, M., Flores, H., and Neaman, A.: Métodos de análisis recomendados para los suelos chilenos, Comisión de Normalización y Acreditación, Sociedad Chilena de la Ciencia del Suelo, Santiago, Chile, p. 150, 2006.

Sarmiento, J. L. and Gruber, N.: Sinks for anthropogenic carbon, Phys. Today, 55, 30-36, 2002.

Schuller, P., Bunzl, K., Voigt, G., Ellies, A., and Castillo, A.: Global fallout ${ }^{137} \mathrm{Cs}$ accumulation and vertical migration in selected soils from South Patagonia, J. Environ. Radioactiv., 71, 43-60, 2004.

Schulz, J. J., Cayuela, L., Echeverria, C., Salas, J., and Benayas, J. M. R.: Monitoring land cover change of the dryland forest landscape of Central Chile (1975-2008), Appl. Geogr., 30, 436-447, 2010 . 
Seguel, O., Farías, E., Luzio, W., Casanova, M., Pino, I., Parada, A., Videla, X., and Nario, A.: Physical properties of soil after change of use from native forest to vineyard, Agro. Sur., 43, 29 39, 2015.

Soto, L., Leiva, E., Montoya, F., Seguel, Ó., Delpiano, C., Becerra, P., Vasquez, I., Miranda, A., and Smith-Ramírez, C.: Effect of Acacia caven (Mol.) on the physical properties of soil under grazing exclusions, AgroCiencia, 31, 211-222, 2015.
Ziolkowski, L. A., Wierzchos, J., Davila, A. F., and Slater, G. F.: Radiocarbon evidence of active endolithic microbial communities in the hyperarid core of the Atacama Desert, Astrobiology, 13, 607-616, 2013. 